\title{
Epidural Anesthesia for a Patient with Ebstein's Anomaly posted for Transurethral Resection of Prostate
}

\author{
${ }^{1}$ Grama S Karthik, ${ }^{2}$ Madihalli JI Sowmya, ${ }^{3}$ Hiremathada Sahajananda, ${ }^{4}$ S Shruthi Shree, ${ }^{5}$ Ramegowda Sudheer
}

\begin{abstract}
Ebstein's anomaly is an abnormality of the tricuspid valve in which valve leaflets are malformed or displaced downwards into the right ventricle. Patient may develop supraventricular dysrhythmias leading to syncope, cyanosis, congestive heart failure and sudden death.

The choice of anaesthesia is individualized and remains a challenge. We managed one such patient under Epidural Anesthesia successfully. Epidural Anesthesia in a fractionated and graded manner provides a hemodynamically stable patient with adequate intra and post-operative analgesia
\end{abstract}

Keywords: Congestive heart failure, Ebstein's anomaly, Epidural anesthesia, Tachyarrythmias, Transurethral resection of prostate.

How to cite this article: Karthik GS, Sowmya MJI, Sahajananda H, Shree SS, Sudheer R. Epidural Anesthesia for a Patient with Ebstein's Anomaly posted for Transurethral Resection of Prostate. J Med Sci 2018;4(1):23-24.

Source of support: Nil

Conflict of interest: None

\section{INTRODUCTION}

Ebstein's anomaly is an abnormality of the tricuspid valve in which the valve leaflets are malformed or displaced downward into the right ventricle. Patient can present with supraventricular dysarrythmias that leads to congestive heart failure (CHF), worsening cyanosis, syncope, and sudden death. ${ }^{1,2}$

Here we report a case of a patient with Ebstein's anomaly posted for transurethral resection of prostate (TURP).

\section{CASE REPORT}

A 65-year-old male was admitted to the urology department with symptoms of benign prostatic hyperplasia. He was posted for TURP. He had no history of recurrent chest infections, dyspnea on exertion, cyanosis, or palpitations.

\footnotetext{
1,2,4 Associate Professor, ${ }^{3}$ Professor and Head, ${ }^{5}$ Resident

${ }^{1-5}$ Department of Anesthesiology, RajaRajeshwari Medical College \& Hospital, Bengaluru, Karnataka, India
}

Corresponding Author: Madihalli JI Sowmya, Associate Professor, Department of Anesthesiology, RajaRajeshwari Medical College \& Hospital, Bengaluru, Karnataka, India, e-mail: drsowmyamj@yahoo.com

\section{EXAMINATION}

On examination, the pulse rate was found to be $92 \mathrm{bpm}$ regular, blood pressure was $130 / 80 \mathrm{mmHg}$, airway was mallampatti grade II, his weight was $76 \mathrm{~kg}$, and height was $156 \mathrm{~cm}$. His systemic examination was unremarkable. On auscultation, systolic murmur was heard in the tricuspid area with loud S2.

Hemoglobin level was $10.8 \mathrm{mg} / \mathrm{dL}$, electrocardiogram (ECG) showed sinus rhythm, and an echocardiogram revealed a displaced tricuspid valve, intact inter-atrial septum with mildly dilated right atrium, and right ventricle along with moderate tricuspid regurgitation. The ejection fraction was $60 \%$ without any regional wall motion abnormality. Written informed anesthesia consent was taken preoperatively.

After securing an 18-gauge intravenous (IV) cannulae, antibiotics were administered (for infective endocarditis prophylaxis). Patient was started on normal saline. In the operating room all standard monitors $\left[\mathrm{SpO}_{2}\right.$, noninvasive blood pressure (NIBP), ECG] were connected, and a defibrillator was kept ready. Under aseptic precautions, an epidural catheter was inserted through the L4 to L5 space with a 20-gauge Tuohy needle by loss of resistance technique. A test dose of $2 \mathrm{~mL}$ of $2 \%$ lignocaine with adrenaline was given after negative aspiration of blood or cerebrospinal fluid.

Subsequently, $7 \mathrm{~mL}$ of $0.75 \%$ of ropivacaine was administered in graded doses to achieve adequate level of block (up to T10). Patient was hemodynamically stable throughout the procedure. Intraoperatively, his mean arterial pressure was between 80 and $90 \mathrm{~mm} \mathrm{Hg}$ and heart rate was between 80 and $90 \mathrm{bpm}$. He did not develop any arrhythmia or signs of CHF. Surgery was limited to 1 hour. After the surgical procedure, $20 \mathrm{mg}$ of furosemide was given IV.

Patient was monitored in the ICU for first 24 hours for any signs of $\mathrm{CHF}$, and arrhythmias along with vital parameters (heart rate, $\mathrm{NIBP}, \mathrm{SpO}_{2}$ ).

\section{DISCUSSION}

The severity of hemodynamic derangements in patients with Ebstein's anomaly depends on the degree of displacement and functional status of tricuspid valve. ${ }^{3-6}$ Most patients who have an interatrial communication (atrial septal defect, PFO) can develop CHF, worsening 
cyanosis, paradoxical embolization, brain abscess, and sudden death. Basic goals in these patients are to maintain sinus rhythm, preload, after load, and to prevent the increase in the magnitude of right to left intracardiac shut. ${ }^{6-8}$ Case studies have reported on successful use of epidural anesthesia with intact interatrial septum and good ventricular function. ${ }^{3,4,8-11}$ Although general anesthesia is considered safe, we administered epidural anesthesia for this patient as a result of assessing the patient's sensorium in the event of hyponatremia, if TURP syndrome develops. Supraventricular arrhythmias can occur during general anesthesia if proper depth is not achieved (lighter plain of anesthesia). ${ }^{10,12}$

Fluid or acid-base disturbances need to be avoided. Invasive cardiac monitoring using central venous cannulation was not used in this case, as it may lead to complications, such as tachyarrythmias or bacterial endocarditis. ${ }^{3,11}$ We preferred ropivacaine, as it has least cardiotoxic effects. Phenylephrine is indicated for hypotension. ${ }^{5,11}$ It may reflexively decrease the heart rate or terminate arrhythmias like supraventricular tachycardia (SVT). If SVT develops, beta-blockers/adenosine can be used. Calcium-channel blockers are avoided, as they exert negative inotropic effects.

Postoperatively, the patient received epidural analgesia with $0.2 \%$ ropivacaine. In this case, this would help in preventing tachycardia, exacerbation of arrhythmias, and right ventricle dysfunction.

\section{CONCLUSION}

Ebstein's anomaly has a varied spectrum of presentation. The choice of anesthesia is individualized and remains a challenge to the anesthesiologist. We hereby conclude the successful management of a patient with Ebstein's anomaly posted for TURP under epidural anesthesia.

\section{REFERENCES}

1. Hines RL, Marschall KE. Stoelting's coexisting diseases and anaesthesia. Philadelphia (PA): Elsevier; 2004.

2. Oliver WC, Lynch JJ. Congenital heart disease. In: Fleisher LA, editor. Anaesthesia and uncommon diseases. 5th ed. Philadelphia (PA): Elselvier; 2006. pp. 77-126.

3. Chatterjee S, Sengupta I, Mandal R, Sarkar R, Chakraborty PS. Anaesthesia management of caesarean section in patients with Ebstetin's anamoly. Indian J Anaesth 2008 Mar;52(3): 321-323.

4. Halpern S, Gidwaney A, Gates B. Anaesthesia for cesearean section inpreeclamptic patient with Ebstein's anamoly. Can Anaesth Soc J 1985 May;32(3 Pt 1):244-247.

5. Jacobson L, Turnquist K, Masley S. Wolff-Parkinson-White syndrome. Termination of paroxysmal supraventricular tachycardia with phenylephrine. Anaesthesia 1985 Jul;40(7): 657-660.

6. Sushma KS, Shaikh S, Ashwini HR. Anaesthesia management in a parturient with Ebstein's anamoly. J Obstet Anaesth Crit Care 2013 Dec;3(2):101-103.

7. Attenhofer Jost $\mathrm{CH}$, Connolly HM, Edwards WD, Hayes D, Warnes CA, Danielson GK. Ebstein's anamoly - review of a multifacetatedcongenital cardiac condition. Swiss Med Wkly 2005 May;135(19-20):269-281.

8. Khatib SK, Tadwalkar GV. Anaesthesia implications of Ebstein's anamoly: a report of two cases. Anesth Pain Intensive Care 2012;16(1):60-63.

9. Giuliani ER, Fuster V, Brandenberg RO, Mair DD. Ebsteins anamoly: the clinical features and natural history of Ebstein's anomaly of the tricuspid valve. Mayo Clin Proc 1979 Mar;54(3): 163-173.

10. Linter SP, Clarke K. Caesarean section under extradural analgesia in a patient with Ebstein's anamoly. Br J Anaesth 1984 Feb;56(2):203-205.

11. Ratna D, Tejesh CA, Manjunath AC, Thomas MK. Anesthesia for incidental surgery in a patient with Ebstein's Anamoly. SAARC J Anaesth 2008;1(1):85-87.

12. Grover VR, Mahajan RP, Sharma S, Singh H. Anaesthesia for incidental surgery in a patient with Ebstein's anamoly. Indian J Anaesth 1987 Jun;35(3):223-228. 